\title{
CORRESPONDENCE
}

\section{High vascularity in bones of dinosaurs, mammals and birds}

\author{
(Plate 1)
}

SIR - The high vascularity of the compact bone of dinosaurs, seen by Bakker $(1972$, p. 82) as evidence of endothermy, is wrongly explained in a recent text intended for students (Ostrom, 1981). In a section on bone structure (p. 26), microscopical resemblances between their bone and that of mammals and birds are first noted and then explained as follows: ' Compact or dense bone of many living ectotherms contains few primary vascular canals, the sites of blood vessels. By contrast, the compact bone of many mammals and birds is penetrated by large numbers of vascular channels, but here they are termed secondary canals because the bone tissue surrounding them clearly shows that it has been reconstructed, i.e. the bone tissues themselves have been remodelled, resorbed and rebuilt (see Pritchard, CBR No. 47).

A student who relies on this text will be led to suppose that a hig', vascularity in bone from dinosaurs, mammals or birds is always due to Haversian reconstructio*, and never a primary feature. But, Seitz (1907) showed that the compact bone of dinosaurs may ' jw numerous primary canals, which were not formed by internal reconstruction (in, for example, Diplodocus: see his pp. 304-5 and pl. 9. Fig. 47). Gross (1934) and Currey (1960) both showed that the typically high vascularity of laminar bone sensu Gross (e.g. Gross, 1934, figs 6, 7, 9-12, 17; Currey, 1962, pl. 36, figs 1-3), found in various members of these groups as well as some thecodontians and therapsids, is a primary vascularity owing nothing to Haversian reconstruction; and Smith (1960) showed the same for related types of bone, grouped with laminar bone by de Ricqlès $(1974,1975)$ as fibro-lamellar bone. Further, Gross (1934), Smith (1960) and Currey (1960) all showed that the osteons, which enclose the vascular canals of fibro-lamellar bone, are not replacive secondary osteons, but primary osteons whose formation does not involve remodelling. The prosauropod bone found by Currey (1962) to be more vascular than in mammals of comparable size was primary laminar bone, and not replacive Haversian bone (cf. Ostrom, 1980, p. 41) which he only discussed incidentally.

It is important for students to realize that the vascular canals and osteon systems, seen in compact bone of dinosaurs and mammals, are both of two different kinds with different origins. Primary canals result from the enclosure of superficial blood vessels, as new bone is added at the periosteal surface In the simplest cases (Plate 1, fig. 1), the spaces enclosed are little bigger than the blood vessels, and then only interrupt the periosteal bone without further complications; but, in others, the spaces are larger, and become the sites for internal deposition of lamellar or parallel-fibred bone (Plate 1, fig. 2; cf. Currey, 1960, fig. 3). This bone is said to form primary osteons (Gross, 1934, p. 739; Smith, 1960, pp. 331-3). Because the bone forming them is deposited concentrically around blood vessels, these structures resemble the replacive secondary osteons of Haversian bone; but their formation is not a remodelling process, and does not involve the resorption of pre-existing bone.

Secondary canals are instead formed when existing canals are first enlarged, by resorption of bone which surrounds them, and the bone removed is then replaced by new concentrically deposited lamellar bone (Plate 1, fig. 5). This process produces structures called secondary osteons, or typical Haversian systems, each of which has a secondary vascular canal at its centre. They are distinctively outlined by a peripheral cementing line, which marks the limit of outward resorption, and hence is not seen around primary osteons. At first it is the primary canals which are affected; but the process is often repeated, so that secondary osteons and canals are produced in successive generations. The ultimate result is a tissue called dense Haversian bone (Plate 1, fig. 4), in which all primary bone has been replaced, and the original pattern of primary canals has been obliterated. The contrast and relationship between primary and Haversian compact bone, as seen in mammals and dinosaurs, is brought out clearly by Halstead (1974, figs $10.3,10.4$; 1981, pls $\mathrm{x}$, xi), although not all bone with primary osteons shows the laminar pattern which he illustrates.

The types of primary compact bone called fibro-lamellar by de Ricqlès (1974, p. 53 and fig. $2 ; 1975$, pp. 88-92), described by Smith (1960, pp. 331-3) in his sections headed 'Woven-fibred bone' and 'Primary osteones', include laminar bone sensu Gross (Plate 1, figs 2, 3; called 'plexiform bone' by

Geol. Mag. 120 (2), 1983, pp. 191-194. Printed in Great Britain. 
Enlow \& Brown (1957); not their 'laminar bone' or that of Enlow (1969), which is a form of Gross's (1934) zonal bone) and other types which are similar histologically. During their formation, a finely cancellous framework of woven bone (seen in Plate 1, fig. 2) is first laid down periosteally, enclosing spaces which may form an irregular labyrinth, or consist of longitudinal tunnels or of radial or circumferential clefts. Primary osteons are then formed within these spaces (Smith, 1960, pl. 2, figs 1-5; Currey, 1960, fig. 3), following patterns (cf. de Ricqlès, 1974, fig. 2) which the form of the spaces determines, and may comprise the major part of the tissue when its growth is complete. These types of bone, found in mammals, birds and dinosaurs, all show a high vascularity which is primary, and not a result of Haversian reconstruction.

It is therefore extremely misleading to imply that the vascular canals seen in compact bone of mammals, birds and dinosaurs are always secondary canals, formed due to bone being 'remodelled, resorbed and rebuilt' (cf. Ostrom, 1981, p. 26). When the bone is fibro-lamellar, its high vascularity is primary, and unrelated to Haversian reconstruction; and the primary compact bone of dinosaurs was fibro-lamellar in most currently known cases (cf. de Ricqlès, 1980, p. 114-15, table 1). Highly vascular primary zonal bone is also known from some genera (e.g. Plate 1, fig. 5, upper part, and Reid, 1981, figs $1 c-e$ ). Secondary Haversian reconstruction was certainly often extensive, as a further development; but this is not why their bones were highly vascular, any more than it is in a mammal with laminar primary compact bone. And, in dinosaurs, Haversian reconstruction sometimes markedly reduced vascularity (Plate 1, fig. 6). Further, Pritchard (1979, pp. 6-7) did not claim or imply that the vascular canals seen in mammals are always secondary canals. He described the growth of primary osteons as 'secondary ossification' (my italics), because it follows the formation of a framework of non-lamellar (woven) bone, and the production of secondary osteons in Haversian reconstruction as 'tertiary ossification'. In other words, he used the term 'secondary' in two conflicting senses, with reconstruction implied in 'secondary osteon' but not in 'secondary ossification'. He also noted that the primary bone of mammals is not always reconstructed, in even parts of some large bones; and his example (the femur in oxen) was one source of the material used by Currey $(1960,1962)$ in his studies of laminar bone mammals and dinosaurs.

Last, it also is misleading to treat claims that the structure of their bones shows that dinosaurs were endotherms as based solely on reconstructed Haversian bone. Bakker (e.g. 1972, 1975) and de Ricqlès (e.g. 1974, 1976, 1980) have both emphazied its presence in dinosaurs, because of their view of its physiological significance; but de Ricqlès (e.g. 1976, pp. 139-40 and 142-3) has based a different argument on primary structure and growth rates. This argument is not my topic here; but it ought to be explained in the text meant for students, and pointed out as not based on reconstructed bone.

\section{References}

Bakker, R. T. 1972. Anatomical and ecological evidence of endothermy in dinosaurs. Nature, Lond. 238, $81-5$.

Bakker, R. T. 1975. Dinosaur renaissance. Scient. Am. 232(4), 58-78.

Currey, J. D. 1960. Differences in the blood supply of bone of different histological types. $Q$. $J$. microsc. Sci. 101, 351-70.

Currey, J. D. 1962. The histology of the bone of a prosauropod dinosaur. Palaeontology 5, 238-246.

Enlow, D. H. 1969. The bone of reptiles. In Biology of the Reptilia vol. 1 (ed. C. Gans and A. d'A. Bellairs), pp. 45-80. London: Academic Press.

Enlow, D. H. \& Brown, S. O. 1957. A comparative histological study of fossil and Recent bone tissues. Part II. Tex. J. Sci. 9, 186-214.

Gross, W. 1934. Die Typen der mikroskopischen Knochenbaues bei fossilen Stegocephalen und Reptilien. Z. Anat. 103, 731-64.

Halstead, L. B. 1974. Vertebrate Hard Tissues. London \& Winchester: Wykeham Science Series.

Halstead, L. B. \& Halstead, J. 1981. Dinosaurs. Poole Dorset: Blandford Press.

Ostrom, J. H. 1980. The evidence for endothermy in dinosaurs. In $A$ Cold Look at the Warm-blooded Dinosaurs (ed. R. D. K. Thomas and E. C. Olson), pp. 15-54. AAAS Selected Symposium 28, Boulder, Colorado: Westview Press.

Ostrom, J. H. 1981. Dinosaurs. Carolina Biology Readers 98. Burlington, N. Carolina. 
Pritchard, J. J. 1979. Bones. Carolina Biology Readers 47, 2nd ed. Burlington, N. Carolina.

Reid, R. E. H. 1981. Lamellar-zonal bone with zones and annuli in the pelvis of a sauropod dinosaur. Nature, Lond. 292, 49-51.

Ricqlès, A. J. de 1974. Evolution of endothermy: histological evidence. Evol. Theory 1, 51-80.

Ricqlès, A. J. de 1975. Recherches paléohistologiques sur les os longs des tétrapodes. VII. Sur la classification, la signification fonctionelle et l'histoire des tissues osseux des tétrapodes. Première partie: structures. Ann. Paléont. (Vertébrés) 61(1), 49-129.

Ricqlès, A. J. de 1976. On bone histology of fossil and living reptiles, with comments on its functional and evolutionary significance. In Morphology and Biology of Reptiles (ed. A. d'A Bellairs and C. B. Cox), pp. 123-150, Linn. Soc. Lond. Symp. 3, London: Academic Press.

Ricqlès, A. J. de 1980. Tissue structures of dinosaur bone. In A Cold Look at the Warm-blooded Dinosaurs (ed. R. D. K. Thomas and E. C. Olson), pp. 103-39. AAAS selected symposium 28, Colorado: Westview Press. Boulder.

Seitz, A. L. L. 1907. Vergleichende Studien über den mikroskopischen Knochenbau fossiler und rezenter Reptilien und dessen Bedeutung für das Wachstum und Umbildung des Knochengewebes im allgemeinen. Nova Acta abh. Kaiser Leop. Carol. Deutsch. Akad. Naturforsch. 87(2), 230-370. Smith, J. W. 1960. Collagen fibre patterns in mammalian bone. J. Anat., Lond. 94, 329-44.

Department of Geology

R. E. H. REID

The Queen's University of Belfast

Belfast BT7 1NN

Northern Ireland

22nd April 1982 


\section{EXPLANATION OF PLATE}

Plate 1. Photomicrographs showing primary and secondary vascularity in compact bone from dinosaurs. 1-1, Simple primary vascular canals, which were formed by enclosure of blood vessels as new bone was added at the external (periosteal) surface (seen at top). Some minor internal deposition has also occurred, but there are no well-developed primary osteons. Rhabdodon (a smaller late Cretaceous relative of Iguanodon), indet. limb bone; $\times 52$; B.M. (N.H.) R. 3814. 1-2, Fibro-lamellar bone, developed as laminar bone (sensu Gross, 1934, and Currey, 1960; not 'laminar' bone sensu Enlow (1969), which is a form of Gross's (1934) zonal bone). Rapid periosteal growth has first produced a cavernous framework of woven bone (seen as dark trabeculae), within which primary osteons (the lighter material) have then formed around blood vessels. The high vascularity of bone of this type has no connection with Haversian remodelling, in either mammals or dinosaurs (see also Currey, 1960, pp. 352-6 and figs 2, 3; but note that the 'bright lines' he describes in material from cattle are not present in the dinosaur). Indet. sauropod ('Cetiosaurus') limb bone; $\times 52$; OUM J. 29835/p2. 1-3, Laminar bone affected locally by Haversian remodelling, which has led to the formation of scattered secondary osteons. The laminar tissue was already highly vascular before this process began, and most of the vascular canals are still primary ones. Compare with Halstead, 1974, fig. 10.4, which shows similar material. Iguanodon, indet. limb bone (? tibia), shaft (diaphysis); $\times 26$; B.M. (N.H.) R. 6458. 1-4, Dense Haversian bone, formed entirely from successive generations of secondary osteons, and from a different part of the same bone as fig. 1-3. Despite repeated reconstruction, this bone is no more vascular than the original laminar bone it has replaced (cf. also Currey's, 1960, pp. 360-1, comments on laminar and Haversian bone in cattle). R. 6458, near distal end (metaphysis); $\times 26.1-5$. The process of Haversian reconstruction, as seen in a case in which Haversian bone was spreading outwards when the animal died. (a) Primary (unremodelled) compact bone, containing numerous primary osteons and primary canals. A resorption canal has begun to develop at bottom right. (b) Bone with large lacunae, produced by resorption, some of which have been partly infilled by centripetal deposition of new lamellar bone. The partially infilled lacunae show the start of the process by which secondary osteons are formed. $(c)$ Bone with fully formed secondary osteons, seen in section as 'Haversian systems', which were produced by infilling of lacunae like those seen above (in $b$ ) until only a small secondary vascular canal remained unfilled at the centre of each osteon. There are also some interstitial traces of the primary tissues (periosteal bone s.s. and primary osteons). The large size of the secondary osteons compared with the primary ones (see $a$ ) is frequently a feature of Haversian bone (cf. also, for example, figs 1-3, 1-4). Megalosaurus; pubis; $\times 26$; OUM J. 29797/pl. 1-6. Bone in which formation of large secondary osteons has led to reduced (not increased) vascularity. Compare the numerous vascular canals seen in the unremodelled primary bone (non-laminar fibro-lamaellar bone; see $a$ ) with the few seen in the Haversian bone below (see $b$ ). The boundary between unremodelled and Haversian bone slopes downward to the right. Tyrannosaurus rib; × 26; B.M. (N.H.) R. 7995.

Together, Figures 1-2, 1-3 and 1-6(a) also illustrate the presence of fibro-lamellar bone (de Ricqlès, e.g. 1974), with high primary vascularity, in three widely different dinosaurs: a sauropod (fig. 1-2), an ornithopod (figs 1-3) and a carnosaur (fig. 1-6,a). Figure 1-1 and 1-5 are from bones in which the primary compact bone is instead of Gross's (1934) zonal type, with 'growth rings', but primary vascular canals are still present in both cases. 
Geol. Mag. Vol. 120, 1983, Reid, Plate I, facing page 194.
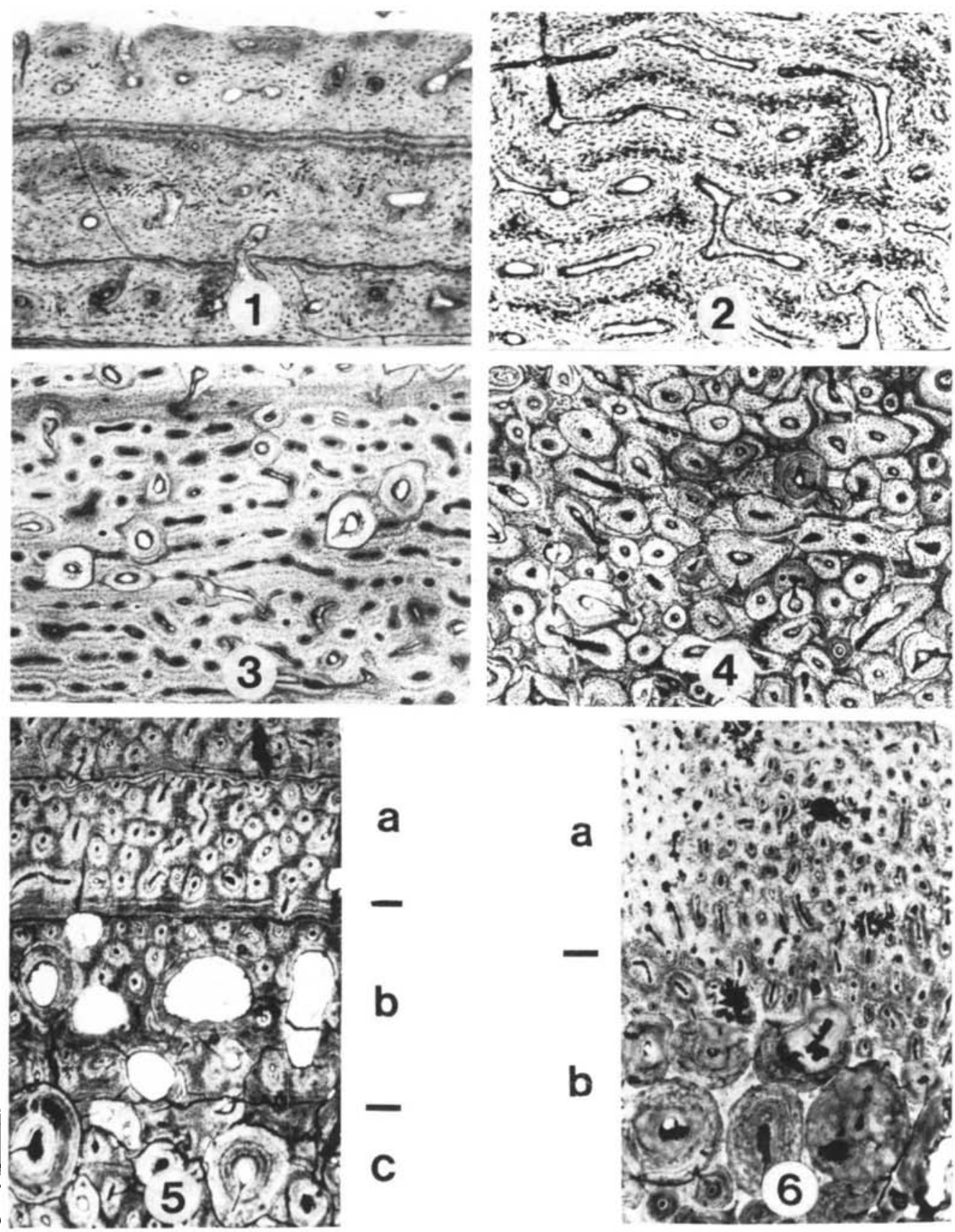

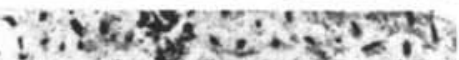
$\therefore, 5030,3400$

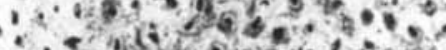

a

b

C

Plate 1. Compact bone from dinosaurs. 